\title{
A SARS-CoV-2-ellenes antitestekkel végzett terápia helye a COVID-19 kezelésében
}

\author{
Fábián Ákos dr. \\ Debreceni Egyetem, Általános Orvostudományi Kar, Klinikai Központ, \\ Aneszteziológiai és Intenzív Terápiás Tanszék, Debrecen
}

\begin{abstract}
Az új típusú koronavírus (SARS-CoV-2) okozta fertőzés és a COVID-19 elleni küzdelem egyik lehetősége a SARSCoV-2-ellenes neutralizáló antitestekkel végzett passzív immunizáció. Az utóbbi időben számos készítmény jutott el a klinikai kipróbálásig. Az alábbiakban áttekintjük ezen készítmények legfőbb tulajdonságait és az antitest-terápiával elért klinikai eredményeket. Ezek alapján elsősorban prehospitálisan, az állapotprogresszió szempontjából leginkább veszélyeztetett populációnál alkalmazva, e készítmények jelentősen csökkenthetik az állapotromlás esélyét és a kórházi ellátás igényét, ezáltal javíthatják a kimenetelt, és mérsékelhetik az egészségügyi ellátórendszer terhelését. Orv Hetil. 2021; 162(51): 2030-2039.
\end{abstract}

Kulcsszavak: COVID-19, kezelés, antitest-terápia, bamlanivimab, etesivimab, casirivimab, imdevimab, sotrovimab, regadanvimab

\section{The role of SARS-CoV-2 antibody therapy in the treatment of COVID-19}

Passive immunization is a therapeutic option in the fight against the infection caused by the novel coronavirus (SARS-CoV-2) and COVID-19. Significant advances have been made in the development of SARS-CoV-2 neutralizing antibodies. Here we discuss the antibodies under clinical trial and the published data regarding their clinical efficacy. Based on these, when given to non-hospitalized patients at high risk for disease progression, these antibodies can significantly reduce worsening of the disease and the need for hospitalization. This can improve the outcomes of patients and help reduce the burden on the healthcare system.

Keywords: COVID-19, treatment, antibody therapy, bamlanivimab, etesivimab, casirivimab, imdevimab, sotrovimab, regadanvimab

Fábián Á. [The role of SARS-CoV-2 antibody therapy in the treatment of COVID-19]. Orv Hetil. 2021; 162(51): 2030-2039.

(Beérkezett: 2021. október 4.; elfogadva: 2021. október 21.)

\section{Rövidítések}

ACE2 = (angiotensin-converting enzyme 2) angiotenzinkonvertáló enzim-2; $\mathrm{ADE}=$ (antibody-dependent enhancement) antitestfüggő fertőződésfokozódás; BMI = (body mass index $)$ testtömegindex; COVID-19 = (coronavirus disease 2019) koronavírus-betegség 2019; EMA = (European Medicines Agency) Európai Gyógyszerügynökség; EUA = $($ emergency use authorization) vészhelyzeti felhasználási engedély; Fab = (fragment antigen-binding) antigénkötő fragmentum; $\mathrm{Fc}=$ (fragment crystallizable) kristályosítható fragmentum; FDA = (U.S. Food and Drug Administration) amerikai Élelmiszer- és
Gyógyszerügyi Hivatal; $\mathrm{HC}=$ (heavy chain) nehéz lánc; $\mathrm{HR}=$ (hazard ratio) kockázati arány; $\mathrm{LC}=$ (light chain) könnyü lánc; $\mathrm{NTD}=\mathrm{N}$-terminális domén; $\mathrm{OR}=($ odds ratio $)$ esélyhányados; $\mathrm{PCR}=$ (polymerase chain reaction) polimeráz-láncreakció; $\mathrm{RBD}=$ (receptor-binding domain) receptorkötő domén; RBM $=($ receptor-binding motif $)$ receptorkötő motívum; RNS $=$ ribonukleinsav; SARS-CoV-2 = (severe acute respiratory syndrome coronavirus 2) súlyos akut légúti tünetegyüttest okozó koronavírus-2; TMPRSS2 = transzmembrán proteáz-szerin-2; VOC $=($ variant of concern $)$ aggodalomra okot adó vírusvariáns 
A SARS-CoV-2-fertózés által okozott COVID-19 -pandémia az elmúlt évek egyik legjelentősebb válsághelyzetét idézte elő az egészségügyben. A helyenként drasztikus járványügyi intézkedések és a teljes egészségügyi mozgósítás ellenére 2021 októberéig közel 235 millió fertőzést és 4,8 millió, a fertőzéssel összefüggésbe hozható halálesetet regisztráltak [1].

A járvány kezdete óta nagy erókkel folyik a hatékony gyógymódok kutatása, fejlesztése. A hagyományos és újgenerációs technológiákon alapuló vakcinák kifejlesztésével felcsillant a járvány letörésének lehetősége, azonban a változó mértékủ átoltottság és az újabb vírusvariánsok megjelenése révén ez eddig nem realizálódott. A hazánkban most erősödő negyedik hullámban így ismét várható a betegszám emelkedése. Számos egyéb terápiás lehetőség mellett a SARS-CoV-2-ellenes neutralizáló monoklonális antitestekkel végzett passzív immunizáció segíthet az elsősorban enyhe és középsúlyos esetekben a betegségprogresszió és a hospitalizáció megelőzésében. Az alábbiakban ezen antitestek alkalmazásának elméleti hátterét, a velük végzett klinikai tanulmányok eredményeit tekintjük át.

\section{A SARS-CoV-2 felépítése és funkcionális sajátosságai}

A SARS-CoV-2 a béta-koronavírusok nemzetségébe tartozó, pozitív egyszálú RNS-vírus. A genomja összesen 4 struktúrfehérjét kódol: nukleokapszid $(\mathrm{N})$, spike/tüske (S), membrán (M) és envelope/burok (E) [2]. Ezek közül az S-fehérje felelős a vírus gazdasejtbe hatolásáért. Az S-fehérjék a vírus felszínén homotrimerként találhatók meg, az általuk képzett kiboltosulások okozzák a vírusra jellegzetes, „napkorona”-szerü megjelenést. Az S-fehérje S1 és S2 alegységekből épül fel [3]. Az S1-alegységen található a receptorkötő domén (receptorbinding domain, RBD), amely a gazdasejtnek az angiotenzin-konvertáló enzim-2 (ACE2) receptoraihoz kötődik. Az RBD-n belül található a receptorkötő motívum (receptor-binding motif, RBM), amely ténylegesen felelós az ACE2-vel való interakcióért. Az RBM enyhén konkáv felszínú, és egy taréj található az egyik oldalán [4]. Az RBM-en kívül az S1-alegységen belül megkülönböztetünk N-terminális domént (NTD) is [5]. A receptorhoz kötődést követôen a sejtfelszínen található transzmembrán proteáz-szerin-2 (TMPRSS2) lehasítja az S1-alegységet, és ezáltal felfed egy fúziós domént az S2alegységen, amely segítségével a vírus fuzionál a gazdasejttel, majd internalizálódik [6].

$\mathrm{Az}$ S-fehérje két konformációs állapotban létezik. A prefúziós „down” állapotban a trimer $3 \mathrm{RBD}$-je szorosan összefekszik, ezáltal nem képes kötődni az ACE2receptorhoz [7]. A gazdasejt megfertőzéséhez az RBDnek előbb az „up” pozícióba kell kerülnie, ekkor válik alkalmassá a receptor megkötésére. Ez a konformációváltozás dinamikus, részben a közeg pH-ja határozza meg [8]. A konformáció egyúttal meghatározza a hozzáfér- hető epitópokat is, így az egyes antitestek az általuk felismert epitóp függvényében az S-fehérjét adott esetben csak az „up” vagy „down” állapotban képesek megkötni [9].

Az S-fehérje a fertózésben betöltött szerepe miatt a különböző vakcinafejlesztések és antitest-terápiák fő célpontja [10]. A feltételezés az volt, hogy mivel az RBD ACE2-kötése a vírus gazdasejtbe hatolásának kulcsfontosságú lépése, ez egy konzervált régiója lesz a fehérjének. Ezzel szemben bebizonyosodott, hogy az RBD viszonylag nagy változatosságot mutat [11], számos mutáció megváltoztatja a fehérje antitestek általi felismerhetőségét anélkül, hogy érdemben befolyásolná a fehérje receptorkötő funkcióját.

\section{SARS-CoV-2-ellenes monoklonális antitestekkel végzett terápia: preklinikai adatok}

A humán antitestek (más néven immunglobulinok) két egyforma nehéz láncból (heavy chain, HC) és két egyforma könnyú láncból (light chain, LC) állnak (1. ábra) [12]. Egy HC és egy LC diszulfidhidakkal kapcsolódik egymáshoz, majd egy másik azonos heterodimerrel alkotják a teljes heterotetramer immunglobulint. Az immunglobulin három funkcionális részből áll: két, antigénfelismerésért felelős fragmentumból (Fab), amelyek egy kapocsrégión keresztül csatlakoznak az izotípusra jellemző, kristályosítható fragmentumhoz $(\mathrm{Fc})$. A Fab fragmentumok felelősek az antigénkötéséért, de önmagukban effektorfunkcióval nem rendelkeznek. Az Fc fragmentum határozza meg az izotípust és az effektorfunkciókat.

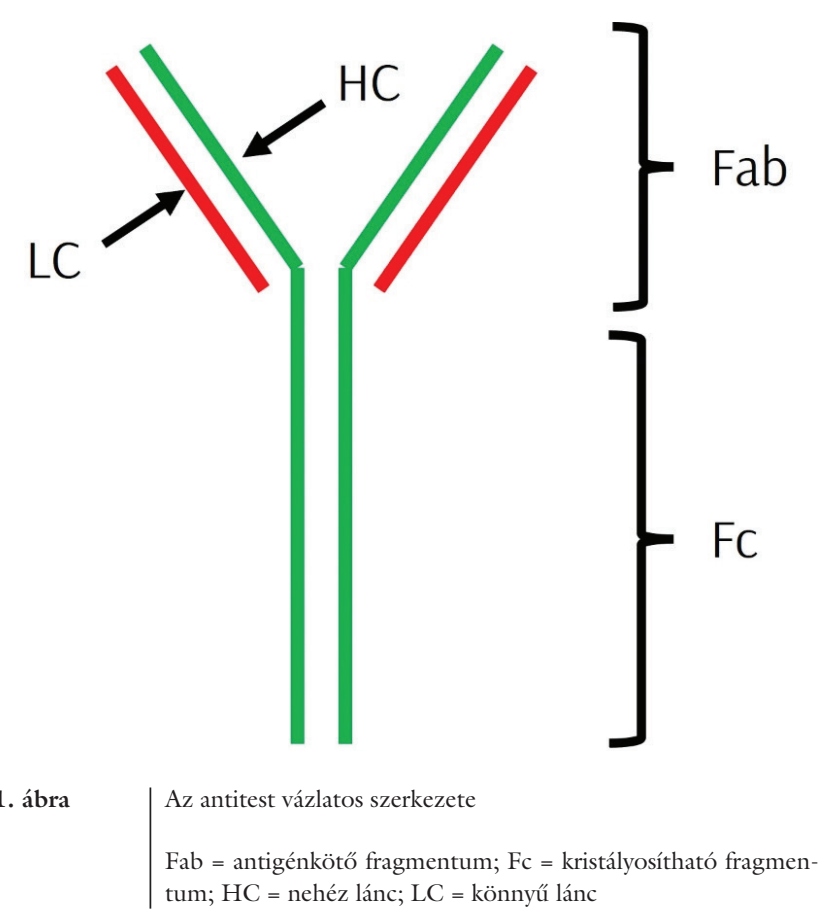


A SARS-CoV-2 ellen jelenleg klinikai kipróbálás alatt vagy elörehaladott fejlesztési fázisban lévő monoklonális antitestek többnyire az S-fehérje RBD- vagy NTD-részét ismerik fel, és IgG-típusúak [9]. A legtöbb, RBD-t kötő antitest vagy közvetlenül megakadályozza az RBDACE2 interakciót, vagy gátolja az RBD „up” konformációba való átváltását $[13,14]$. Az antitesteket a kötődési sajátosságaik alapján több osztályba lehet sorolni [15]:

- I. osztály: az RBM-hez kötődnek, gátolják az ACE2 kötését, csak az „up” konformációban kötődnek az RBD-hez.

- II. osztály: az RBM-hez kötődnek, gátolják az ACE2 kötését, „up” és „down” konformációban is kötődnek az RBD-hez.

- III. osztály: az RBM-mel nem átfedő konzervált régióhoz kötődnek, „up” és „down” konformációban is kötődnek az RBD-hez, a szomszédos RBD-protomerekkel is kölcsönhatásba lépnek.

- IV. osztály: az RBM-mel nem átfedő konzervált régióhoz kötődnek, csak „up” konformációban kötik.

A klinikai gyakorlatban is alkalmazott antitestek a bamlanivimab [16] és etesemivab, a casirivimab és imdevimab [17], a sotrovimab [18], és a regdanvimab [19]. A casirivimab és etesevimab az I. osztályba, a bamlanivimab és imdevimab a II. osztályba, a sotrovimab pedig a III. osztályba tartozik [5, 20]. Ezen antitesteket többnyire SARS-CoV-2-infekción átesett betegekből izolálták. Kivétel a sotrovimab, amelyet egy 2003-ban SARSCoV-fertőzésen átesett beteg memória-B-sejtjeiból azonosítottak, és keresztreaktivitást mutatott a SARSCoV-2-vel [18]. Jelenleg mindegyik készítmény az Európai Gyógyszerügynökség (EMA) által végzett folya- matos értékelés alatt áll, amely a végleges engedélyezést hivatott felgyorsítani [21]. Az eddig felsoroltakon túl további ígéretes antitestek tartanak a preklinikai vagy korai klinikai vizsgálati fázisban [22-25].

\section{Antitest-rezisztencia és kivédése}

Számos, aggodalomra okot adó vírusvariáns (variant of concern, VOC) esetén vizsgálták a klinikailag alkalmazott monoklonális antitestekkel szembeni rezisztenciát (1. táblázat) [26, 27]. Ezek jellemzően olyan vírusvariánsok, amelyek gyorsabban terjednek, súlyosabb kórlefolyást okoznak, vagy valamilyen okból fokozott terápiás nehézséget idéznek elő (például csökkent neutralizáló titer), mint a vadtípus . A B.1.1.7-es változattal szemben gyakorlatilag az összes monoklonális antitest megőrzi hatékonyságát, de a B.1.35l-es változattal szemben a bamlanivimab és a casirivimab ineffektív volt [28]. $\mathrm{Az}$ etesevimab ugyancsak ineffektívnek bizonyult [6], ugyanakkor a külső felszínhez kötődő imdevimab ezen változat ellen is hatékony maradt [28]. A P.l-es variáns ellen egyedül az imdevimab órizte meg hatékonyságát, a bamlanivimab, casirivimab és etesevimab neutralizáló hatása teljesen megszünt vagy jelentősen csökkent [29]. A B.1.617-es variánssal szemben a bamlanivimab ismételten ineffektív volt, a casirivimab hatékonysága csökkent, az imdevimab és az etesevimab azonban megőrizte hatékonyságát [6]. Az imdevimabnak a B.1.617-es variánssal szembeni aktivitását illetően van ennek ellentmondó eredmény is, bár a casirivimabbal kombinált készítmény ott is megőrizte hatékonyságát [30].

1. táblázat | SARS-CoV-2-VOC-ok, a variánsra jellemző mutáció(k) és a monoklonális antitestek variáns elleni neutralizáló aktivitása

\begin{tabular}{|c|c|c|c|c|c|}
\hline & & \multicolumn{4}{|c|}{ Vírusvariáns } \\
\hline & & $\begin{array}{l}\text { Alfa - B.1.1.7 } \\
\text { (korábbi „brit”) }\end{array}$ & $\begin{array}{l}\text { Béta - B.1.351 } \\
\text { (korábbi „dél-afrikai”) }\end{array}$ & $\begin{array}{l}\text { Gamma - P.1 } \\
\text { (korábbi „brazil”) }\end{array}$ & $\begin{array}{l}\text { Delta -B.1.617.1 } \\
\text { (korábbi „indiai”) }\end{array}$ \\
\hline \multicolumn{2}{|c|}{ Mutáció (RBD): } & N501Y & K417N, E484K, N501Y & K417T, E484K, N501Y & $\mathrm{L} 452 \mathrm{R}, \mathrm{E} 484 \mathrm{Q}$ \\
\hline \multicolumn{2}{|c|}{ Mutáció (S1/S2): } & D614G, P681H & D614G & D614G, H655Y & D614G, P681R \\
\hline \multirow[t]{6}{*}{ Antitest } & $\begin{array}{l}\text { Bamlanivimab } \\
\text { (LY-CoV555) }\end{array}$ & $\checkmark$ & $x$ & $x$ & $x$ \\
\hline & $\begin{array}{l}\text { Etesevimab } \\
(\mathrm{LY}-\mathrm{CoV016})\end{array}$ & $\checkmark$ & $x$ & $x$ & $\checkmark$ \\
\hline & $\begin{array}{l}\text { Casirivimab } \\
\text { (REGN10933) }\end{array}$ & $\checkmark$ & $x$ & $x$ & $\checkmark$ \\
\hline & $\begin{array}{l}\text { Imdevimab } \\
\text { (REGN10987) }\end{array}$ & $\checkmark$ & $\checkmark$ & $\checkmark$ & $\checkmark$ \\
\hline & $\begin{array}{l}\text { Sotrovimab } \\
(\text { VIR-7831) }\end{array}$ & $\checkmark$ & $\checkmark$ & $\checkmark$ & $\checkmark$ \\
\hline & $\begin{array}{l}\text { Regdanvimab } \\
\text { (CT-P59) }\end{array}$ & $\checkmark$ & $x$ & $x$ & $x$ \\
\hline
\end{tabular}

$\checkmark$ : hatékony (a neutralizáló aktivitás csökkenése <10-szeres); × : nem hatékony (a neutralizáló aktivitás csökkenése >10-szeres) [26, 27]

$\mathrm{NA}=$ nincs adat; RBD = receptorkötő domén; SARS-CoV-2 = súlyos akut légúti tünetegyüttest okozó koronavírus-2; VOC = aggodalomra okot adó vírusvariáns 
A monoklonálisantitest-terápia egyik lehetséges nem kívánt mellékhatása, hogy a szelekciós nyomás révén az antitest-terápiának ellenálló, az alól kibúvó, úgynevezett „escape” variánsok kiválasztódásához vezet. Feltételezések szerint az RBD-n belül különböző epitópokat felismerő monoklonális antitestek együttes adása csökkentheti az „escape” variánsok kialakulását [31]. A késóbbiekben in vitro sikerült igazolni, hogy egy monoklonális antitest vagy két különböző, de átfedő epitópokat felismerő antitestek alkalmazása valóban „escape” variánsokat szelektál, ám két különböző, nem átfedő epitópokat felismerő monoklonális antitest alkalmazása esetén nem lép fel ez a jelenség [30]. Az „escape” variánsok kialakulásának megelőzésére egy másik stratégia az olyan mesterséges antitestek alkalmazása, amelyek több különböző antitest antigénkötő régióját is tartalmazzák, ezáltal egyszerre több epitóphoz tudnak kötődni [32].

\section{Az Fc fragmentum funkcionális szerepe}

$\mathrm{Az}$ antitestfejlesztés egyik nyitott kérdése az Fc fragmentum szerepe és ennek megfelelően potenciális módosítása. Az Fc fragmentum módosítása lehetővé teszi az antitest felezési idejének nyújtását, másrészt a receptorkötés megváltoztatásával modulálhatók az antitestfüggő effektorfunkciók [3, 33], de akár befolyásolható az antitest szöveti sequestratiója is [34].

Az antitestalapú terápiák (aktív és passzív immunizáció) egyik potenciális buktatója az antitestfüggő fertőződésfokozódás (antibody-dependent enhancement, $\mathrm{ADE}$ ), amelyet már számos vírusfertózés kapcsán sikerült kimutatni [35]. Ennek során a nem megfelelő neutralizáló aktivitással rendelkező antitestek a vírushoz kötődve paradox módon nem terápiás hatásúak, hanem betegségprogressziót okoznak. Két lehetséges mechanizmusa lehet a jelenségnek, amelyek szorosan kötődnek az Fc fragmentumhoz: egyrészt fokozott antitestfüggő intracelluláris vírusfelvétel a phagocytasejtek Fc $\gamma$ RIIa-receptorához kötődés miatt vagy az antitest $\mathrm{Fc}$ fragmentum által kiváltott túlzott effektorválasz (például komplementaktiváció) vagy immunkomplexek képződése [35]. Egyelőre SARS-CoV-2-fertőzés kapcsán nem rendelkezünk ADE kialakulására utaló adatokkal. Ugyanakkor állatkísérletben igazolták, hogy míg a monoklonális antitest preexpozíciós védelméhez nem szükséges az Fc fragmentum effektorfunkciója, addig kialakult fertőzés esetén elengedhetetlen a terápiás hatékonysághoz [36, 37].

\section{SARS-CoV-2 ellenes monoklonális antitestekkel végzett terápia: klinikai eredmények}

A továbbiakban bemutatott klinikai tanulmányokkal és eredményeikkel kapcsolatban meg kell jegyezni, hogy egy részüket eddig még csak lektorálatlan közleményként publikálták. Másrészt, mint arra egy aktuális Coch- rane-analízis is rámutat [38], a kimeneteli végpontok kevés betegnél következtek be, így a tényleges klinikai hatékonyságot illetően még jelentős bizonytalanság áll fenn. A klinikai eredmények áttekintése a 2. táblázatban található [39-51].

\section{Bamlanivimab és etesivimab}

2020 novemberében a monoklonális antitestek közül elsóként a bamlanivimab kapott vészhelyzeti felhasználási engedélyt (emergency use authorization, EUA) az amerikai Élelmiszer- és Gyógyszerügyi Hivataltól (U.S. Food and Drug Administration, FDA) [31]. Az etesivimabbal alkotott kombinációs készítmény 2021 februárjában kapta meg ugyanezt az engedélyt [31].

Először a BLAZE-1 tanulmányban vizsgálták az antitestek virológiai és klinikai hatékonyságát [39]. A randomizált, kettős-vaktanulmány 2. fázisában 452 járóbeteg bamlanivimabot $(700 \mathrm{mg}, 2800 \mathrm{mg}$ vagy $7000 \mathrm{mg}$ dózisban) vagy placebót kapott. Mindegyik beteg enyhe COVID-19-tüneteket mutatott, és kevesebb mint 3 nap telt el az első pozitív virológiai mintavétel után. Az elsődleges kimeneteli végpont a vírustiter csökkenése volt a 11. napra. A különböző dózisokban alkalmazott bamlanivimabkezelés a placebóhoz képest $-0,2(700 \mathrm{mg})$, -0,53 (2800 mg), és 0,09 (7000 mg) $\log _{10} \mathrm{kópia/ml-rel}$ csökkentette a vírustitert (a logaritmusos skála miatt ez a 2800 mg-os dózis esetén 3,4-szeres titercsökkenésnek felelt meg). A bamlanivimabkezelésben részesülő csoportban a betegek 1,6\%-a, míg a placebocsoportban a betegek 6,3\%-a igényelt kórházi vagy sürgősségi betegellátó osztályos kezelést.

A tanulmány 2. fázisának folytatásában az azonos módszerrel beválogatott betegek random módon placebót vagy bamlanivimab + etesevimab $(2800 \mathrm{mg}+2800$ mg) kezelést kaptak [40]. Összesen 613 beteg adatait dolgozták fel. A vírustiter változása a placebóhoz képest a végső analízis során 0,09 (700 mg), -0,27 (2800 mg), 0,31 (7000 mg), és -0,57 (kombinált kezelés) $\log _{10}$ víruskópia/ml lett (a korábban közölt adatoktól való eltérést a további, placebokezelést kapó betegek miatt változó placebo-csoportátlag okozhatta). Egyedül a kombinált bamlanivimab + etesevimab kezelés esetén volt statisztikailag szignifikáns a vírustiter csökkenése. Az összes bamlanivimabbal kezelt csoportban kevesebb volt a kórházi vagy sürgősségi betegellátó osztályos kezelést igénylő betegek száma, azonban a placebocsoportban is csak 9 beteg igényelt ilyen ellátást, ezért a különbség nem érte el a statisztikai szignifikanciát.

A BLAZE-1 tanulmány 3. fázisában 1035 , enyhe vagy közepesen súlyos COVID-19-beteg - akiknél legalább egy kockázati tényezője volt a súlyos betegségbe való progressziónak (életkor $>65$ év, BMI>35, immunszuppresszió, krónikus cardiovascularis, metabolikus, máj-, vese- vagy tüdőbetegség) - kapott placebo- vagy bamlanivimab + etesevimab (2800 mg + $2800 \mathrm{mg})$ kezelést [39]. A kezelés itt is a SARS-CoV-2-fertőzés 
2. táblázat | A SARS-CoV-2-ellenes neutralizáló antitestekkel végzett klinikai tanulmányok összesítése [39-51]

\begin{tabular}{|c|c|c|c|c|}
\hline \multicolumn{5}{|c|}{ Alkalmazás: járóbetegek } \\
\hline Antitestkészítmény & Dózis & Vizsgálati populáció & Eredmény & \\
\hline Bamlanivimab & $\begin{array}{l}0,7 \mathrm{~g} \\
2,8 \mathrm{~g} \\
7 \mathrm{~g}\end{array}$ & $\begin{array}{l}\text { Enyhe COVID-betegek } \\
+\mathrm{PCR}<3 \text { nap }\end{array}$ & $\begin{array}{l}\text { A 11. napra szignifikánsan csökkent a virustiter } \\
\text { a } 2800 \text { mg-os dózis mellett; } \\
\text { mAb-kezelés mellett kevesebb kórházi megjelenés }\end{array}$ & [39] \\
\hline \multirow[t]{2}{*}{$\begin{array}{l}\text { Bamlanivimab }+ \\
\text { etesevimab }\end{array}$} & $2,8+2,8 \mathrm{~g}$ & $\begin{array}{l}\text { Enyhe COVID-betegek } \\
+\mathrm{PCR}<3 \text { nap }\end{array}$ & $\begin{array}{l}\text { A 11. napra szignifikánsan csökkent a virustiter } \\
\text { a kombinált kezelés mellett; } \\
\text { mAb-kezelés mellett kevesebb kórházi megjelenés }\end{array}$ & {$[40]$} \\
\hline & $2,8+2,8 \mathrm{~g}$ & $\begin{array}{l}\text { Enyhe vagy közepesen súlyos COVID- } \\
\text { betegek } \\
\text { A betegségprogresszió kockázata: magas } \\
+ \text { PCR <3 nap }\end{array}$ & $\begin{array}{l}\text { A } 29 \text { napon belüli hospitalizáció vagy halál } \\
\text { kockázata csökkent mAb-terápia mellett } \\
\text { RKCs: } 70 \%\end{array}$ & {$[41]$} \\
\hline \multirow[t]{2}{*}{$\begin{array}{l}\text { Casirivimab }+ \\
\text { imdevimab }\end{array}$} & $\begin{array}{l}2,4 \mathrm{~g} \\
8 \mathrm{~g}\end{array}$ & $\begin{array}{l}\text { Enyhe vagy közepesen súlyos COVID- } \\
\text { betegek } \\
+ \text { SARS-CoV-2-teszt }<3 \text { nap } \\
\text { Tünetek }<12 \text { nap }\end{array}$ & $\begin{array}{l}\text { A 7. napra szignifikánsan csökkent a virustiter } \\
\text { mAb-kezelés mellett } \\
\text { A } 29 \text { napon belül orvosi ellátást igénylö betegek } \\
\text { aránya csökkent mAb-kezelés mellett } \\
\text { RKCs: } 57-84 \% \text { (a kockázati tényezők és a } \\
\text { serostatus függvényében) }\end{array}$ & {$[42,43]$} \\
\hline & $\begin{array}{l}1,2 \mathrm{~g} \\
2,4 \mathrm{~g}\end{array}$ & $\begin{array}{l}\text { Enyhe vagy közepesen súlyos COVID- } \\
\text { betegek } \\
\text { A betegségprogresszió kockázata: magas } \\
\text { + SARS-CoV-2-teszt <3 nap } \\
\text { Tünetek < } 12 \text { nap }\end{array}$ & $\begin{array}{l}\text { A tünetek szanálódása gyorsabb mAb mellett } \\
\text { A } 29 \text { napon belüli hospitalizáció vagy halál } \\
\text { kockázata csökkent mAb-terápia mellett } \\
\text { RKCs: } 70,4 \% \text { és } 71,3 \%\end{array}$ & {$[44]$} \\
\hline Sotrovimab & $0,5 \mathrm{~g}$ & $\begin{array}{l}\text { Enyhe vagy közepesen súlyos COVID- } \\
\text { betegek } \\
\text { A betegségprogresszió kockázata: magas } \\
\text { Tünetek }<5 \text { nap }\end{array}$ & $\begin{array}{l}\text { A } 29 \text { napon belüli hospitalizáció vagy halál } \\
\text { kockázata csökkent mAb-terápia mellett } \\
\text { RKCs: } 85 \%\end{array}$ & {$[45]$} \\
\hline Regdanvimab & $40,80 \mathrm{mg} / \mathrm{kg}$ & $\begin{array}{l}\text { Enyhe vagy közepesen súlyos COVID- } \\
\text { betegek } \\
\text { Tünetek }<7 \text { nap }\end{array}$ & $\begin{array}{l}\text { A klinikai tünetmentesség mAb-terápia mellett } \\
\text { gyorsabban alakult ki }(5,4 \text { nap/ } 6,2 \text { nap vs. } 8,8 \text { nap }) \\
\text { Az oxigénterápia vagy hospitalizáció igénye } \\
\text { csökkent mAb-terápia mellett }(4,0 \% / 4,9 \% \text { vs. } 8,7 \%)\end{array}$ & {$[46]$} \\
\hline \multicolumn{5}{|c|}{ Alkalmazás: fekvőbetegek } \\
\hline Antitestkészítmény & Dózis & Vizsgálati populáció & Eredmény & \\
\hline Bamlanivimab & $7 \mathrm{~g}$ & $\begin{array}{l}\text { Enyhe vagy közepesen súlyos COVID- } \\
\text { betegek } \\
\text { Tünetek < } 12 \text { nap }\end{array}$ & $\begin{array}{l}\text { Idő előtt leállítva } \\
\text { A teljes populációban nem volt különbség: } \\
\text { az } 5 \text {. napi tüdőstatusban, } \\
\text { a } 28 \text { napon belüli felépülésben, } \\
\text { a } 90 \text { napon belüli halálozásban }\end{array}$ & {$[47]$} \\
\hline $\begin{array}{l}\text { Casivivimab + } \\
\text { imdevimab }\end{array}$ & $8 \mathrm{~g}$ & $\begin{array}{l}\text { Enyhe vagy közepesen súlyos COVID- } \\
\text { betegek } \\
\text { Tünetek: átlagosan } 9 \text { nap }\end{array}$ & $\begin{array}{l}\text { Szeronegatív betegekben csökkent a } 28 \text { napon } \\
\text { belüli halálozás ( } 24 \% \text { vs. } 30 \%) \\
\text { Szeronegatív betegekben csökkent a kórházban } \\
\text { töltött idő ( } 13 \text { nap vs. } 17 \text { nap) }\end{array}$ & {$[48]$} \\
\hline Sotrovimab & & $\begin{array}{l}\text { Enyhe vagy közepesen súlyos COVID- } \\
\text { betegek } \\
\text { Tünetek <12 nap }\end{array}$ & Hatékonyság hiányában idő eloótt leállítva & {$[49]$} \\
\hline \multicolumn{5}{|c|}{ Alkalmazás: prevenció } \\
\hline Antitestkészítmény & Dózis & Vizsgálati populáció & Eredmény & \\
\hline Bamlanivimab & $4,2 \mathrm{~g}$ & $\begin{array}{l}\text { Szociális és ápolási otthonok lakói és } \\
\text { személyzete } \\
\text { Intézményben igazolt pozitív eset } \\
<7 \text { nap }\end{array}$ & $\begin{array}{l}\text { A } 8 \text { hetes COVID-incidencia mAb-profilaxis } \\
\text { mellett csökkent } \\
\text { OR: } 0,43\end{array}$ & {$[50]$} \\
\hline $\begin{array}{l}\text { Casivivimab + } \\
\text { imdevimab }\end{array}$ & $1,2 \mathrm{mg} \mathrm{sc}$. & $\begin{array}{l}\text { SARS-CoV2-fertőzöttekkel egy } \\
\text { háztartásban élők } \\
\text { Diagnózistól tünetek <96 óra }\end{array}$ & $\begin{array}{l}\text { A } 28 \text { napon belüli tünetes SARS-CoV-2-infekció } \\
\text { incidenciája mAb-profilaxis mellett csökkent } \\
\text { RKCs: } 81,4 \% \\
\text { A } 28 \text { napon belüli SARS-CoV-2-infekció incidenci- } \\
\text { ája mAb-profilaxis mellett csökkent } \\
\text { RKCs: } 66,4 \%\end{array}$ & {$[51]$} \\
\hline
\end{tabular}

COVID = koronavírus-betegség; $\mathrm{mAb}$ = monoklonális antitest; $\mathrm{OR}$ = esélyhányados; $\mathrm{PCR}$ = polimeráz-láncreakció; RKCs = relatívkockázat-csökkenés; SARS-CoV-2 = súlyos akut légúti tünetegyüttest okozó koronavírus-2 
laboratóriumi diagnózisától számított 3 napon belül indult. Az elsődleges kimeneteli végpont a 29 napon belüli hospitalizáció vagy halál volt. A monoklonális antitestekkel végzett terápiában részesülő betegek 2,1\%ánál, a placebocsoportban a 7,0\%-uknál következett be az elsődleges végpont, ami 70\%-os relatívkockázat-csökkenésnek felelt meg. A 7. napon mért vírustiter-változás különbsége a placebóhoz képest -1,20 $\log _{10}$ víruskópia/ $\mathrm{ml}$ volt. A bamlanivimab + etesevimab csoportban nem volt halálozás. Ezzel szemben a placebocsoportban 9, COVID-19-hez köthető haláleset történt.

A bamlanivimab klinikai alkalmazása hospitalizált betegek esetén kevésbé volt sikeres. Az ACTIV-3/TICO bamlanivimabtanulmányban igazolt SARS-CoV-2-fertőzéssel és 12 napnál nem régebbi tünetekkel hospitalizált betegek részesültek véletlenszerúen placebo- vagy bamlanivimab- (7000 mg) kezelésben [47]. Az elsődleges végpont a 90 napon belüli felépülés volt. Egy 314 beteg után elvégzett hatékonysági elemzés azt találta, hogy a bamlanivimab- és a placebocsoport között nem volt különbség az 5. napi tüdőstatusban, illetve a 28 nap alatt elért felépülésben vagy kórházi elbocsátásban. Ezek alapján a tanulmány folytatását felfüggesztették. Az adatok további elemzése kapcsán megállapították, hogy a felvételkor neutralizáló antitesttiterrel nem rendelkező betegek esetén a bamlanivimabterápia növelte a felépülés arányát a placebóhoz képest (91\% vs. 85\%). Ezzel szemben a neutralizáló antitestekkel rendelkező betegeknél fordított tendenciát figyeltek meg $(87 \%$ vs. $96 \%)$. A teljes populációban az összetett kimeneteli végpont - 90 napon belüli halálozás, szervelégtelenség, súlyos fertőzés és súlyos mellékhatás - előfordulásában nem volt statisztikai különbség a bamlanivimab- (28\%) és a placebo- $(27 \%)$ csoport között. Ugyanígy a 90 napon belüli halálozás is hasonló volt ( $8 \%$ vs. 7\%). Míg azonban a neutralizáló antitestekkel nem rendelkező betegek esetén a bamlanivimabkezelés csökkentette az összetett kimenetel (HR: 0,67), illetve a halálozás (HR: 0,45) kockázatát, addig a neutralizáló antitestekkel rendelkező betegek esetén rontotta a kimenetelt (HR: 1,8, illetve HR: 3,5).

A bamlanivimab alkalmasságát a SARS-CoV-2-fertőzés megelőzésére egy randomizált, kettős vak-, placebokontrollált tanulmány vizsgálta [50]. Szociális és ápolási otthonok lakói és személyzete részesültek placebo- vagy egyszeri bamlanivimab- (4200 mg) kezelésben az intézményben igazolt SARS-CoV-2-fertőzéstől számított 7 napon belül. Összesen 1175 alanyt vontak be a vizsgálatba, akik hetente szolgáltattak PCR-mintát. Az elsődleges kimeneteli végpont a 8 héten belüli COVID-19-incidencia volt. A PCR-rel detektált fertőzéshez képest 21 napon belül jelentkező specifikus tüneteket tekintették COVID-19-esetnek. A beválogatáskor 966 beteg volt PCR-rel és szerológiailag negatív. Ebben a prevenciós populációban a bamlanivimabkezelés szignifikánsan csökkentette a COVID-19 incidenciáját, 15,2\%-ról 8,5\%-ra (OR: 0,43). A mellékhatások tekintetében nem volt szignifikáns különbség a két csoport között.
A fentieken túl fontos megemlíteni, hogy az FDA 2021 áprilisában visszavonta a bamlanivimabra kiadott EUA-t [31], majd 2021. június végén a bamlanivimab + etesevimab kombinációs készítményre kiadott EUA-t is [52], az akkor domináns vírusvariánsokra és a korábban ismertetett rezisztenciaviszonyokra való tekintettel. A kombinációs készítményre azonban bizonyos megkötések mellett 2021. augusztus végén újra megadta az EUA-t [53].

\section{Casirivimab és imdevimab}

Az antitestpár 2 héttel a bamlanivimab után kapta meg az EUA-t az FDA-tól [26]. Először egy adaptív, multicentrikus, randomizált, kettős vak-, placebokontrollált tanulmányban (NCT04425629) vizsgálták a klinikai hatékonyságot [42]. A vizsgálatba nem hospitalizált betegeket válogattak be, akiknek 72 óránál nem régebbi pozitív SARS-CoV-2-tesztjük volt, és a tünetek 7 napnál rövidebb ideig álltak fenn. Az első napon placebót vagy antitestkészítményt kaptak 2400 mg vagy 8000 mg dózisban. A tanulmány 1-2. fázisában az elsődleges kimeneteli végpont a 7 nap alatti vírustiter-változás és a 29 nap alatt orvosi ellátást igénylő betegek százaléka volt. Az első 275 beteg adatait feldolgozó interim elemzés azt mutatta, hogy REGEN-COV (ebben a tanulmányban még REGN-COV2 néven futott a készítmény, a későbbiekben azonban REGEN-COV-ra módosították, ezért a félreértések elkerülése érdekében már az általánosan elterjedt, aktuális néven hivatkozunk a készítményre) mellett szignifikánsan jobban csökken a vírustiter, mint placebo mellett, és ez a hatás kifejezettebb volt a beválogatáskor szérumantitest-negatív populációban. Ezenfelül az orvosi ellátást igénylő esetek száma is szignifikánsan kevesebbnek bizonyult az antitest-terápia mellett. $\mathrm{Az}$ egyes REGEN-COV-dózisok hatékonysága között statisztikailag jelentős különbség nem volt.

A 799 beteg adatait feldolgozó végső analízisben [43] $10^{7} / \mathrm{ml}$ kópiaszámnál magasabb vírustiter esetén a napi átlagos vírustiter-változás különbsége a REGEN-COV és a placebo között $-0,68 \log _{10}$ kópia/ml volt. Ez az érték a beválogatáskor szérumantitest-negatív populációban $-0,73 \log _{10} \mathrm{kópia/ml,} \mathrm{míg} \mathrm{a} \mathrm{teljes} \mathrm{vizsgálati} \mathrm{popu-}$ lációban -0,36 $\log _{10}$ kópia/ml volt (a szerzők a beválogatáskor szérumantitest-pozitív populációra külön lebontva nem adták meg ezt az adatot). A klinikai végpont tekintetében a REGEN-COV-kezelésben részesülők 2,8\%-ának volt legalább egy orvosi ellátást igénylő megjelenése. Ezzel szemben placebo esetén ez 6,5\% volt, ami $57 \%$-os relatívkockázat-csökkenésnek felel meg. A beválogatáskor szérumantitest-negatív csoportban a relatívkockázat-csökkenés $65 \%$ volt. A betegség progressziója szempontjából legalább egy kockázati tényezővel (életkor>50 év, BMI>30, immunszuppresszió, krónikus cardiovascularis, metabolikus, máj-, vese- vagy tüdőbetegség) rendelkező betegeknél 71\% volt a kockázatcsökkenés. Amennyiben emellett szérumantitest- 
negatívak voltak, és az induló vírustiter $10^{4}$ kópia $/ \mathrm{ml}$ fölött volt, úgy az orvosi ellátást igénylő megjelenés tekintetében REGEN-COV-kezelés mellett 84\%-osnak bizonyult a relatívkockázat-csökkenés.

A tanulmány 3. fázisába 4057, COVID-19-járóbeteget vontak be [44]. A beválogatásnak ismét feltétele volt a 72 óránál nem régebbi pozitív SARS-CoV-2-teszt és a 7 napnál rövidebb ideig fennálló tünetek. Az 1., 2. fázis tapasztalatai alapján viszont $2400 \mathrm{mg}$ és $1200 \mathrm{mg}$ REGEN-COV-dózisokat alkalmaztak, és csak a súlyosabb kórlefolyás szempontjából legalább egy kockázati tényezővel rendelkező betegek vettek részt. Az elsődleges kimeneteli végpont ezúttal a 29 napon belüli legalább 1 hospitalizáció vagy halálozás volt. Másodlagos végpont volt a 4. és 29. nap közötti legalább 1 hospitalizáció vagy halálozás, valamint a tünetmentességig eltelt idő. Az elsődleges végpont vonatkozásában a $2400 \mathrm{mg}$ os és 1200 mg-os REGEN-COV-kezelés 71,3\% és 70,4\% relatívkockázat-csökkenést ért el. A kezelés 4 . napját követően az antitest-terápiában részesülő csoportban jelentősen csökkentek a hospitalizációs vagy halálozási események. A tünetek szanálódása átlagosan 4 nappal gyorsabban következett be a kontrollcsoporthoz képest (14 vs. 10 nap). Amennyiben REGEN-COV-kezelés mellett kórházi kezelés vált szükségessé, a betegek átlagosan rövidebb időt töltöttek a kórházban, és ritkábban szorultak intenzív osztályos ellátásra. Mindezek mellett a súlyos mellékhatások előfordulása gyakoribb volt a placebocsoportban (4\%), mint bármelyik REGEN-COVcsoportban ( $1,1 \%$ és $1,7 \%)$.

A casirivimab és imdevimab hatékonyságát a RECOVERY tanulmány vizsgálta COVID-19 miatt kórházban kezelt betegeknél [48]. Összesen 9785 beteget vontak be a vizsgálat ezen szakaszába, akik $8000 \mathrm{mg}$ REGEN-COV- vagy placeboterápiában részesültek. Randomizációkor a betegek átlagosan 9 napos tünetekkel rendelkeztek. Az elsődleges végpont a 28 napon belüli halálozás volt. A beválogatáskor szeronegatív populációban REGEN-COV-kezelés mellett alacsonyabb volt a 28 napos halálozás (24\%), mint a placebocsoportban $(30 \%)$. A teljes populációban nem volt statisztikai különbség a REGEN-COV (20\%) és a placebo (21\%) melletti halálozásban. A REGEN-COV halálozásra kifejtett hatása jelentősen különbözött a szeropozitív és a szeronegatív betegek között. A szeronegatív populációban a REGEN-COV-kezelés hatására szignifikánsan nőtt a 28 napon belüli élve elbocsátás esélye (58\%-ról 64\%-ra), rövidült a kórházban töltött idő (átlagosan 17-ről 13 napra), és csökkent a gépi lélegeztetési igény vagy a halálozás esélye (37\%-ről 30\%-ra). Ugyanakkor a teljes vizsgálati populációban már nem lehetett kimutatni ezeket a különbségeket.

A REGEN-COV-nak a fertőzésprofilaxisra való alkalmasságát is vizsgálták [51]. A vizsgálat során SARSCoV-2-fertőzöttekkel egy háztartásban élő résztvevők a diagnózis felállításától számított 96 órán belül placebót vagy egyszeri REGEN-COV 1200 mg subcutan injekci- ót kaptak. Összesen 1505 alanyt vontak be a vizsgálatba. Az elsődleges végpont a 28 napon belül kialakuló tünetes SARS-CoV-2-infekció volt. Ezt REGEN-COV-kezelés mellett a résztvevők 1,5\%-ánál, míg placebo mellett a 7,8\%-uknál tapasztalták (81,4\% relatívkockázat-csökkenés). A REGEN-COV hatékonyan megelőzte a tünetes és tünetmentes fertőzést (66,4\%-os relatívkockázat-csökkenés). A REGEN-COV-profilaxis mellett kialakult tünetes fertőzés esetén jelentősen csökkent a tünetes időszak (3,2 hétről 1,2-re) és a magas vírustiterrel $\left(>10^{4}\right.$ kópia/ml) töltött idő (1,3-ról 0,4 hétre) is. Ezek alapján az FDA engedélyezte a REGEN-COV alkalmazását posztexpozíciós profilaxisra is [54].

\section{Sotrovimab}

A sotrovimabbal kapcsolatban a COMET-ICE tanulmányból származnak adatok [45], amely egy multicentrikus, kettős vak-, randomizált, 3-as fázisú klinikai tanulmány. Olyan, még nem hospitalizált, tünetes COVID-19-betegeket vontak be a tanulmányba, akiknek legalább egy kockázati tényezőjük (életkor>55 év, diabetes, $B M I>30 \mathrm{~kg} / \mathrm{m}^{2}$, pangásos szívelégtelenség, krónikus veseelégtelenség, közepesen súlyos vagy súlyos asthma) volt a betegség progressziójára. Összesen 583 beteget randomizáltak, hogy placebót vagy sotrovimabból egy egyszeri, 500 mg-os intravénás adagot kapjanak. A betegek legfeljebb 5 napja fennálló tünetekkel rendelkeztek, a súlyos COVID-19 (nyugalmi fulladás, légzési elégtelenség vagy szupplementális oxigénigény) kizárási kritérium volt. Az elsődleges kimeneteli végpont a 29 napon belüli betegségprogresszió volt, amelyet a 24 óránál hosszabb hospitalizációként vagy halálként definiáltak. Ez a végpont 3 esetben (1\%) következett be a sotrovimabcsoportban és 21 esetben (7\%) a kontrollcsoportban, ami 85\%-os relatívkockázat-csökkenés volt a betegség progressziója szempontjából. Összesen 5 beteg került intenzív osztályra, mindannyian placebót kaptak. A mellékhatásokat 868 betegnél mérték fel, előfordulási gyakoriságuk közel azonos volt a sotrovimabbal és a placebóval kezelt csoportban (17\% vs. 19\%).

A sotrovimab hatékonyságát hospitalizált betegeknél az ACTIV-3 tanulmány keretén belül vizsgálták, azonban egy tervezett időközi hatékonysági elemzést követően a tanulmány ezen ágát leállították [49]. Ugyan az elsődleges elemzés alapján teljesítette a folytatáshoz szükséges feltételeket, de a kontrollcsoportban összességében előrehaladottabb betegségük volt az alanyoknak. Miután ezt figyelembe vették, az adatok értékelésekor már hatékonyság hiányában leállították a további betegek bevonását.

\section{Regdanvimab}

A regdanvimabot randomizált, kettős vak-, placebokontrollált, 2. fázisú tanulmányban vizsgálták enyhe és közepesen súlyos COVID-19-járóbetegekben [46]. Beválo- 
gatáskor a tünetek 7 napnál kevesebb ideje álltak fenn. Összesen 307 beteget randomizáltak monoklonális antitesttel (40 mg/kg és $80 \mathrm{mg} / \mathrm{kg}$ csoport) vagy placebóval való kezelésre. Az elsődleges végpont a negatív PCR-ig és a klinikai tünetmentességig eltelt idő volt. A negatív PCR-ig eltelt idő 12,8 és 11,9 nap volt az alacsony, illetve a magas dózisú csoportban, placebo esetén 12,9 nap volt. A klinikai tünetmentességet 5,4 és 6,2 nap alatt érték el az alacsony, illetve a magas dózisú csoportban. Placebo esetén erre átlagosan 8,8 napra volt szükség. Az oxigénterápiát vagy kórházi ellátást igénylő betegek aránya $4,0 \%(40 \mathrm{mg} / \mathrm{kg}), 4,9 \%(80 \mathrm{mg} / \mathrm{kg})$ és $8,7 \%$ (placebo) volt az egyes csoportokban.

\section{A klinikai alkalmazás fóbb szempontjai}

A rendelkezésre álló klinikai tanulmányok alapján a SARS-CoV-2-fertőzés esetén alkalmazott, neutralizáló antitestekkel végzett terápiának néhány általános tendenciája látszik körvonalazódni, amelyeket azok alkalmazása során figyelembe kell venni.

A neutralizáló antitestek a betegség korai fázisában a leghatékonyabbak, ezért minél korábban, lehetőleg már a prehospitális szakaszban kell alkalmazni őket. Ez a gyakorlatban

- az elsö tünetek jelentkezését követö 10 napon belüli, illetve

- a fertőzést megerősítő pozitio PCR-teszthez képest 3 napon belüli beadást jelenti.

A betegség súlyosabb lefolyása szempontjából rizikótényezővel rendelkező betegek esetén nagyobb volt a védőhatás, ezért a neutralizáló antitestek alkalmazása mindenképpen felmerül

- túlsúly (az amerikai ajánlásban már BMI>25 esetén is),

- szív- és érrendszeri betegség (hypertonia, ischaemiás szívbetegség, szívelégtelenség),

- légzöszervi betegség (asztma, krónikus obstruktív tüdőbetegség),

- diabetes,

- krónikus vese-és májelégtelenség,

- immunszupprimált állapot (daganatos alapbetegség, szervátültetett beteg, tartós immunszuppresszív terápia) esetén.

Az alkalmazáskor még saját antitestválasszal nem rendelkező betegek esetén sokkal kifejezettebb volt a védőhatás, így alkalmazás előtt (amennyiben kivitelezhető)

- érdemes felmérni a beteg saját antitestválaszát,

- alacsony anti-S-titer esetén mindenképpen megfontolandó az alkalmazás,

- ugyanakkor szem elött kell tartani, hogy az antitesttiter nem feltétlenül korrelál a neutralizáló aktivitással, így a klinikai állapot függvényében, illetve több kockázati tényezö együttes fennállása esetén magas anti-S-titer mellett is előnyös lehet a neutralizáló antitestek alkalmazása.

$\mathrm{Az}$ egyes vírusvariánsok esetén eltérô lehet a különböző készítmények neutralizáló hatékonysága, ezért az alkalmazni kívánt monoklonális antitest kiválasztásakor figyelembe kell venni

- a beteget fertőzó virusváltozat mutációit, vagy

- amennyiben a szekvenálás klinikai döntésre alkalmas időn belül nem oldható meg, az adott időben az adott régióban legelterjedtebb vírusvariánsok rezisztenciaviszonyait figyelembe véve kell monoklonális antitestet választani.

Az új és hatékony védőoltások ellenére, részben a helyenként alacsony lakossági oltakozási hajlandóság, részben az oltás után idővel csökkenő immunitás és a vírusmutációk miatt létrejövő áttöréses fertőzések következtében, a COVID-19-járványt még nem sikerült legyőzni. Így most, a negyedik hullám kezdetén, ismét lehet számítani a kórházi ellátást igénylő esetek felfutására. Már számos ígéretes gyógyszer áll rendelkezésre a legsúlyosabb kórlefolyás elhárítására. Ezeken belül a SARSCoV-2-ellenes neutralizáló antitestek igazolt klinikai hatékonyságúak, és a betegség elején, elsősorban az állapotprogresszió szempontjából leginkább veszélyeztetett populációnál alkalmazva, jelentősen javíthatják a klinikai kimenetelt. Ezáltal a járvány teljes megfékezéséig fontos elemei terápiás eszköztárunknak és a COVID-19 elleni küzdelemnek.

\section{Megjegyzés}

A közlemény elfogadását követően, 2021. október 29én a bamlanivimab és etesevimab engedélyeztetésére benyújtott kérelmét a fejlesztő cég visszavonta. Az Európai Bizottság 2021 november 12-én az EMA javaslata alapján megadta a forgalomba hozatali engedélyt a Ronapreve (casirivimab és imdevimab) és Regkirona (regdanvimab) készítményekre.

https://www.ema.europa.eu/en/news/ema-ends-rolling-review-antibodies-bamlanivimab-etesevimab-covid19-following-withdrawal-lilly

https://www.ema.europa.eu/en/news/covid-19-emarecommends-authorisation-two-monoclonal-antibodymedicines

Anyagi támogatás: A közlemény megírása anyagi támogatásban nem részesült.

A szerző a cikk végleges változatát elolvasta és jóváhagyta.

Érdekeltségek: A szerzőnek nincsenek érdekeltségei.

\section{Irodalom}

[1] Johns Hopkins University \& Medicine. Coronavirus Resource Center. COVID-19 map. Available from: https://coronavirus. jhu.edu/map.html [accessed: October 4, 2021].

[2] Xiang R, Yu Z, Wang Y, et al. Recent advances in developing small-molecule inhibitors against SARS-CoV-2. Acta Pharm Sin B 2021 Jil 2. [Online ahead of print]. 
[3] Andreano E, Nicastri E, Paciello I, et al. Extremely potent human monoclonal antibodies from COVID-19 convalescent patients. Cell 2021; 184: 1821-1835.el6.

[4] Shang J, Ye G, Shi K, et al. Structural basis of receptor recognition by SARS-CoV-2. Nature 2020; 581: 221-224.

[5] Valdez-Cruz NA, García-Hernández E, Espitia C, et al. Integrative overview of antibodies against SARS-CoV-2 and their possible applications in COVID-19 prophylaxis and treatment. Microbial Cell Fact. 2021; 20: 88.

[6] Hoffmann M, Hofmann-Winkler H, Krüger N, et al. SARS CoV-2 variant B.1.617 is resistant to bamlanivimab and evades antibodies induced by infection and vaccination. Cell Rep. 2021; 36: 109415 .

[7] Riley TP, Chou HT, Hu R, et al. Enhancing the perfusion conformational stability of SARS-CoV-2 spike protein through structure-guided design. Front Immunol. 2021; 12: 660198.

[8] Pramanick I, Sengupta N, Mishra S, et al. Conformational flexibility and structural variability of SARS-CoV2 S protein. Structure 2021; 29: 834-845.e5.

[9] Kumar S, Chandele A, Sharma A. Current status of therapeutic monoclonal antibodies against SARS-CoV-2. PLoS Pathog. 2021; 17: el009885.

[10] Owji H, Negahdaripour M, Hajighahramani N. Immunotherapeutic approaches to curtail COVID-19. Int Immunopharmacol. 2020; 88: 106924.

[11] Liu C, Ginn HM, Dejnirattisai W, et al. Reduced neutralization of SARS-CoV-2 B.1.617 by vaccine and convalescent serum. Cell 2021; 184: 4220-4236.el3.

[12] Chiu ML, Goulet DR, Teplyakov A, et al. Antibody structure and function: the basis for engineering therapeutics. Antibodies (Basel) 2019; 8: 55 .

[13] Cerutti G, Guo Y, Zhou T, et al. Potent SARS-CoV-2 neutralizing antibodies directed against spike $\mathrm{N}$-terminal domain target a single supersite. Cell Host Microbe 2021; 29: 819-833.e7.

[14] Tortorici MA, Beltramello M, Lempp FA, et al. Ultrapotent human antibodies protect against SARS-CoV-2 challenge via multiple mechanisms. Science 2020; 370: 950-957.

[15] Barnes CO, Jette CA, Abernathy ME, et al. SARS-CoV-2 neutralizing antibody structures inform therapeutic strategies. Nature 2020; 588: 682-687.

[16] Jones BE, Brown-Augsburger PL, Corbett KS, et al. The neutralizing antibody, LY-CoV555, protects against SARS-CoV-2 infection in nonhuman primates. Sci Transl Med. 2021; 13: eabfl 1906 .

[17] Hansen J, Baum A, Pascal KE, et al. Studies in humanized mice and convalescent humans yield a SARS-CoV-2 antibody cocktail. Science 2020; 369: 1010-1014.

[18] Pinto D, Park YJ, Beltramello M, et al. Cross-neutralization of SARS-CoV-2 by a human monoclonal SARS-CoV antibody. Nature 2020; 583: 290-295.

[19] Kim C, Ryu DK, Lee J, et al. A therapeutic neutralizing antibody targeting receptor binding domain of SARS-CoV-2 spike protein. Nat Commun. 2021; 12: 288.

[20] Greaney AJ, Starr TN, Barnes CO, et al. Mapping mutations to the SARS-CoV-2 RBD that escape binding by different classes of antibodies. Nat Commun. 2021; 12: 4196

[21] European Commission. COVID-19 therapeutics strategy: Commission identifies five promising candidate therapeutics. Brussels, 29 June 2021. Available from: https://ec.europa.eu/commission/presscorner/detail/en/ip_21_3299 [accessed: October 4, 2021].

[22] Guo Y, Huang L, Zhang G, et al. A SARS-CoV-2 neutralizing antibody with extensive spike binding coverage and modified for optimal therapeutic outcomes. Nat Commun. 2021; 12: 2623

[23] Lanini S, Milleri S, Andreano E, et al. A single intramuscular injection of monoclonal antibody MAD0004J08 induces in healthy adults SARS-CoV-2 neutralising antibody titres exceeding those induced by infection and vaccination. medRxiv
2021.08.03.21261441; doi: https://doi.org/10.1101/2021.0 8.03.21261441.

[24] Bordoloi D, Xu Z, Ho M, et al. Identification of novel neutralizing monoclonal antibodies against SARS-CoV-2 spike glycoprotein. ACS Pharmacol Transl Sci. 2021; 4: 1349-1361.

[25] Meng X, Wang P, Xiong Y, et al. Safety, tolerability, pharmacokinetic characteristics, and immunogenicity of MW33: a phase 1 clinical study of the SARS-CoV-2 RBD-targeting monoclonal antibody. Emerg Microbes Infect. 2021; 10: 1638-1648.

[26] Corti D, Purcell LA, Snell G, et al. Tackling COVID-19 with neutralizing monoclonal antibodies. Cell 2021; 184: 30863108 .

[27] National Institutes of Health. Coronavirus disease 2019 (COVID-19). Treatment guidelines. Available from: https:// www.covid19treatmentguidelines.nih.gov/ [accessed: October $4,2021]$

[28] Wang P, Nair MS, Liu L, et al. Antibody resistance of SARSCoV-2 variants B.1.351 and B.1.1.7. Nature 2021; 593: 130135.

[29] Wang P, Casner RG, Nair MS, et al. Increased resistance of SARS-CoV-2 variant P.1 to antibody neutralization. Cell Host Microbe 2021; 29: 747-751.e4.

[30] Chen RE, Winkler ES, Case JB, et al. In vivo monoclonal antibody efficacy against SARS-CoV-2 variant strains. Nature 2021; 596: 103-108.

[31] Nathan R, Shawa I, De La Torre I, et al. A narrative review of the clinical practicalities of bamlanivimab and etesevimab antibody therapies for SARS-CoV-2. Infect Dis Ther. 2021; 10: 19331947.

[32] De Gasparo R, Pedotti M, Simonelli L, et al. Bispecific IgG neutralizes SARS-CoV-2 variants and prevents escape in mice. Nature 2021; 593: 424-428

[33] Pecetta S, Finco O, Seubert A. Quantum leap of monoclonal antibody $(\mathrm{mAb})$ discovery and development in the COVID-19 era. Semin Immunol. 2020; 50: 101427.

[34] Cathcart AL, Havenar-Daughton C, Lempp FA, et al. The dual function monoclonal antibodies VIR-7831 and VIR-7832 demonstrate potent in vitro and in vivo activity against SARS-CoV-2. bioRxiv 2021.03.09.434607; doi: https://doi.org/10.1101/ 2021.03.09.434607.

[35] Lee WS, Wheatley AK, Kent SJ, et al. Antibody-dependent enhancement and SARS-CoV-2 vaccines and therapies. Nat Microbiol. 2020; 5: 1185-1191.

[36] Winkler ES, Gilchuk P, Yu J, et al. Human neutralizing antibodies against SARS-CoV-2 require intact $\mathrm{Fc}$ effector functions for optimal therapeutic protection. Cell 2021; 184: 1804-1820. el6.

[37] Suryadevara N, Shrihari S, Gilchuk P, et al. Neutralizing and protective human monoclonal antibodies recognizing the $\mathrm{N}$-terminal domain of the SARS-CoV-2 spike protein. Cell 2021; 184: 2316-2331.e15.

[38] Kreuzberger N, Hirsch C, Chai KL, et al. SARS-CoV-2-neutralising monoclonal antibodies for treatment of COVID-19. Cochrane Database Syst Rev. 2021; 9: CD013825.

[39] Chen P, Nirula A, Heller B, et al. SARS-CoV-2 neutralizing antibody LY-CoV555 in outpatients with Covid-19. N Engl J Med. 2021; 384: 229-237.

[40] Gottlieb RL, Nirula A, Chen P, et al. Effect of bamlanivimab as monotherapy or in combination with etesevimab on viral load in patients with mild to moderate COVID-19: a randomized clinical trial. JAMA 2021; 325: 632-644.

[41] Dougan M, Nirula A, Azizad M, et al. Bamlanivimab plus etesevimab in mild or moderate Covid-19. N Engl J Med. 2021; 385: 1382-1392.

[42] Weinreich DM, Sivapalasingam S, Norton T, et al. REGNCOV2, a neutralizing antibody cocktail, in outpatients with Covid-19. N Engl J Med. 2021; 384: 238-251. 
[43] Weinreich DM, Sivapalasingam S, Norton T, et al. REGENCOV antibody cocktail in outpatients with Covid-19. medRxiv 2021.06.09.21257915; doi: https://www.medrxiv.org/content $/ 10.1101 / 2021.06 .09 .21257915 \mathrm{vl}$.

[44] Weinreich DM, Sivapalasingam S, Norton T, et al. REGENCOV antibody cocktail clinical outcomes study in Covid-19 outpatients. medRxiv 2021.05.19.21257469; https://www. medrxiv.org/content/10.1101/2021.05.19.21257469v2.

[45] Gupta A, Gonzalez-Rojas Y, Juarez E, et al. Early Covid-19 treatment with SARS-CoV-2 neutralizing antibody sotrovimab. medRxiv 2021 05.27.21257096; doi: https://doi.org/10.1101 /2021.05.27.21257096.

[46] Eom JS, Ison M, Streinu-Cercel A, et al. Efficacy and safety of CT-P59 plus standard of care: a phase $2 / 3$ randomized, doubleblind, placebo-controlled trial in outpatients with mild-to-moderate SARS-CoV-2 infection. Research Square, 15 March 2021. Preprint (Version 1); doi: https://doi.org/10.21203/rs.3.rs$296518 / \mathrm{vl}$

[47] ACTIV-3/TICO LY-CoV555 Study Group, Lundgren JD, Grund B, Barkauskas CE, et al. A neutralizing monoclonal antibody for hospitalized patients with Covid-19. N Engl J Med. 2021; 384: 905-914.

[48] Horby PW, Mafham M, Peto L, et al. Casirivimab and imdevimab in patients admitted to hospital with COVID-19 (RECOVERY): a randomised, controlled, open-label, platform trial. medRxiv 2021.06.15.21258542; doi: https://doi.org/10.1101/2021.0 6.15 .21258542 .

[49] National Institutes of Health. NIH-sponsored ACTIV-3 clinical trial closes enrollment into two sub-studies. Available from: https://www.nih.gov/news-events/news-releases/nih-sponsored-activ-3-clinical-trial-closes-enrollment-into-two-sub-studies [accessed: October 4, 2021].
[50] Cohen MS, Nirula A, Mulligan MJ, et al. Effect of bamlanivimab vs placebo on incidence of COVID-19 among residents and staff of skilled nursing and assisted living facilities: a randomized clinical trial. JAMA 2021; 326: 46-55.

[51] O'Brien MP, Forleo-Neto E, Musser BJ, et al. Subcutaneous REGEN-COV antibody combination to prevent Covid-19. N Engl J Med. 2021; 385: 1184-1195.

[52] Public Health Emergency. Pause in the distribution of bamlanivimab/etesevimab. June 25, 2021. Available from: https:// www.phe.gov/emergency/events/COVID19/investigationMCM/Bamlanivimab-etesevimab/Pages/bamlanivimab-etesevimab-distribution-pause.aspx [accessed: October 4, 2021]

[53] Public Health Emergency. Resumption in use and distribution of bamlanivimab/etesevimab in certain states. August 27, 2021. Available from: https://www.phe.gov/emergency/events/ COVID19/investigation-MCM/Bamlanivimab-etesevimab/ Pages/resumption-in-distribution-bamlanivimabetesevimab. aspx [accessed: October 4, 2021].

[54] U.S. Food and Drug Administration. FDA authorizes REGENCOV monoclonal antibody therapy for post-exposure prophylaxis (prevention) for COVID-19. FDA, Content current as of: 08/10/2021. https://www.fda.gov/drugs/drug-safety-andavailability/fda-authorizes-regen-cov-monoclonal-antibodytherapy-post-exposure-prophylaxis-prevention-covid-19 [accessed: October 4, 2021].

(Fábián Ákos dr., Debrecen, Nagyerdei krt. 98., 4032 e-mail: fabian.akos@med.unideb.hu)

\section{"Consilium in dubiis remedium prudentis est." (Válságos helyzetben a bölcs menedéke a megfontolás.)}

A cikk a Creative Commons Attribution 4.0 International License (https://creativecommons.org/licenses/by/4.0/) feltételei szerint publikált Open Access közlemény, melynek szellemében a cikk bármilyen médiumban szabadon felhasználható, megosztható és újraközölhetö, feltéve, hogy az eredeti szerző és a közlés helye, illetve a CC License linkje és az esetlegesen végrehajtott módosítások feltüntetésre kerülnek. (SID_1) 